\title{
RECORDS OF CHIRONOMIDAE LARVAE LIVING ON OTHER AQUATIC ANIMALS IN BRAZIL
}

\author{
Fabio de Oliveira Roque*, Susana Trivinho-Strixino, Mário Jancso**, Evelise N. Fragoso
}

Biota Neotropica v4 (n2) - http://www.biotaneotropica.org.br/v4n2/pt/abstract?short-communication+bn03404022004

\author{
Date Received 03/16/2004 \\ Revised 08/26/2004 \\ Accepted 09/08/2004
}
Programa de Pós Graduação em Ecologia e Recursos Naturais, Universidade Federal de São Carlos (UFSCar), Laboratório de Entomologia Aquática / Depto de Hidrobiologia / UFSCar, SP, Brasil, CEP: 13565-905, Cx. Postal 676. 3. Phone: 16- 2608316.
* Corresponding author. E-mail address: pfor@iris.ufscar.br
** Cientistas Associados. Ltda.

\begin{abstract}
In this study, we report forty-nine cases of Chironomidae larvae living on other animals in Brazilian aquatic ecosystems, including a wide range of hosts, such as hydrozoans, snails, insects and fish. We also discuss some empirical difficulties to establish the ecological interactions between chironomids and their hosts.
\end{abstract}

Key words: Chironomidae, aquatic insects, mollusks, fish, ecological interaction, hosts

\section{Resumo}

Neste estudo nós reportamos 49 ocorrências de larvas de Chironomidae vivendo sobre o corpo de outros organismos aquáticos, tais como hidrozoários, moluscos, insetos e peixes, em ambientes aquáticos brasileiros. Nós também discutimos algumas dificuldades práticas para se estabelecer o tipo de interação ecológica entre Chironomidae e seus hospedeiros.

Palavras-chave: Chironomidae, insetos aquáticos, moluscos, interações ecológicas, hospedeiros

http://www.biotaneotropica.org.br 


\section{Introduction}

Chironomidae larvae living on different aquatic animals have been reported by many authors (see revisions in Steffan 1967, White et al. 1980, Tokeshi 1993, Tokeshi 1995, Jacobsen 1995, Ashe \& O’Connor 2002). In the Neotropical region, there has been an increasing number of studies on this subject in recent years (Freihofer \& Neil 1967; Fittkau 1974; Roback 1977; Epler 1986; De La Rosa 1992; Epler \& De la Rosa 1995; Gonser \& Spies 1997; Callisto \& Goulart 2000; Dorvillé et al. 2000; Vilella et al. 2002). Particularly in Brazil, our knowledge about these ecological interactions is too fragmented and no attempt has been made to summarize the information already existent.

The primary scope of the present work is to present an updated list of the records of chironomids living on other aquatic animals in Brazilian aquatic systems, including several new concurrencies. Subsequently, we comment on some empirical difficulties and criteria to study interactions between chironomids and their hosts, given that our understanding of natural interactions may be distorted due to many problems, such as: 1) incompleteness, ambiguity and inconsistency of interspecific interactions' definition and classification (see conceptual discussion in Abrams 1987 and Bronstein 2001), and methodological constraints and lack of minimal information necessary to understand the relationship between mechanism and effect related to the ecological interactions.

\section{Material and Methods}

We have gathered data from three different sources: 1) the majority of the new data were obtained from studies on Chironomidae in the State of São Paulo, within the project "Inventory and Biology of freshwater Crustacean, Insects and Mollusks of the State of São Paulo" BIOTA-FAPESP Biodiversity; 2) most larvae of chironomid living on fish were obtained from the project "Inventory of Fish of the Streams from Passa Cinco, State of São Paulo" (Fragoso et al. 2003); 3) we also added information extracted from articles and from personal communication (the identification level and the morphospecies considered by each author were maintained in this work). In sources 1 and 2, the larvae were sorted out from their hosts, mounted in slides, and identified up to the possible taxonomic level, considering the limited knowledge of the Neotropical fauna. Given that most works were not specifically designed to examine ecological interactions between chironomids and their hosts, we do not consider quantitative information in this study.

The organisms are deposited in the collection of the Laboratório de Entomologia Aquática da Universidade Federal de São Carlos, SP, Brazil. We did not include chironomids living in/on freshwater sponges because this subject will be addressed in a future study.

We use the term "interactions between chironomids and their hosts" (ICH) to express all kind of interactions that may be obtained by a direct observation of a chironomid larvae living on the body of other aquatic animal. This term does not implicate in any interpretation of mechanisms and effects of the interaction between organisms. We emphasize our position about the use of some ecological terms, like phoresy, association, symbiosis, commensalisms, and others, which are very dependent on population level information (data not available in this study).

\section{Results and discussion}

\subsection{Brazilian records of chironomids on other freshwater animals}

Forty-nine cases involving Chironomidae living on the bodies of other animals are reported; 20 are new records and 29 are based on other studies or personal communications (Table 1) (Figure 1). The chironomid larvae showed a wide range of hosts (hydrozoans, snails, insects and fish), as pointed out by Steffan (1967) and Tokeshi (1995).

In general, our results corroborate those shown by Tokeshi (1995): amongst insects, Plecoptera, Ephemeroptera, Megaloptera and Odonata were the most frequent hosts. Some characteristics make them suitable as hosts, such as bigger cryptic benthic species with low mobility. Other common aquatic insects like Diptera, Hemiptera and non-insects like Mollusca were poorly represented. We have not found any chironomid living on non-case bearing Trichoptera, Crustacea and Coleoptera, which is probably related to the grooming behavior in the first two groups and smooth tegument in the latter.

In relation to vertebrate hosts, we have added new occurrences of the relatively well reported, but scarcely known interaction between Ichthyocladius and fish (see comments below). It is important to note that although we have found no report on chironomid living on non-fish vertebrates and it is unlike that obligatory relationships between chironomid and these animals exist, we believe that further studies focused on alligators, turtles, aquatic birds, and others vertebrates, would bear interesting results about, for instance, transport of eggs and chironomid larvae.

Species belonging to Corynoneura group were the most frequent in ICH in this study as well as in Tokeshi (1995) and Jacobsen (1995). Some genera within Corynoneura group seem to have species in obligate relationships with their hosts, like Epoicocladius, Nanocladius (Plecopteracoluthus), Symbiocladius, and Tempisquitoneura with species of Ephemeroptera, Megaloptera and/or Plecoptera, and Ichthyocladius (recently placed into Corynoneura group by Mendes et al. 2004) and fish. In this sense, an inevitable question emerges: have obligatory $\mathrm{ICH}$ evolved from commensal ancestors? The subject is controversial (see Jacobsen 1995) but, at least, within the Corynoneura group, the monophyletism 

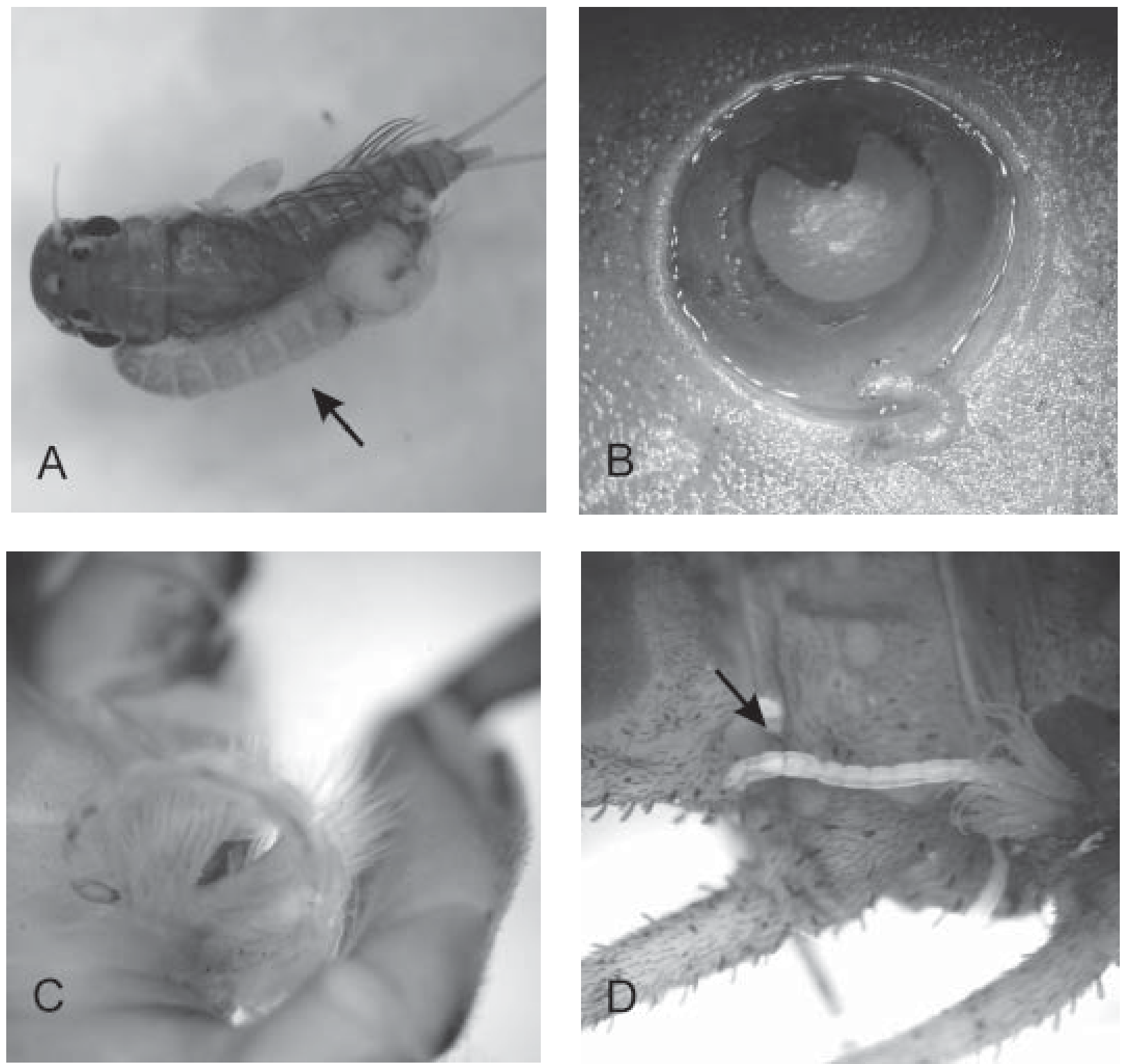

Figure 1. Chironomidae larvae on other aquatic animals. (A) Larva of Corynoneura group sp.2 attached to abdominal segments of Farrodes (Ephemeroptera); (B) Larva of Ichthyocladius attached to head of Hypostomus (Pisces); (C) Larva of Corynoneura group sp.1 attached to thorax of Kempnyia colossica Navás, 1934 (Plecoptera); (D) Larva of Corynoneura attached to abdominal segments of Corydalus (Megaloptera). 
Table 1. Records of chironomid larvae living on other aquatic animals in Brazilian aquatic ecosystems. In order to avoid space-consuming in the table, we included taxa followed by author's name and data only for species level.

Records of chironomid larvae living on other aquatic animals in Brazilian aquatic ecosystems

\begin{tabular}{|c|c|c|c|}
\hline Chironomidae & Host & $\begin{array}{l}\text { Aquatic system, Location } \\
\text { (Geographical coordinates) }\end{array}$ & Reference \\
\hline Cardiocladius & \begin{tabular}{|} 
Pupae of Simulium \\
pertinax Kollar, 1832; and \\
Simulium spinibranchium \\
Lutz 1910 (Diptera)
\end{tabular} & Stream, Pirenópolis, Goiás & Present study \\
\hline cf. Corynoneura & Corydalus (Megaloptera) & $\begin{array}{l}\text { Stream, Serra do Cipó and } \\
\text { Serra da Canastra, Minas } \\
\text { Gerais }\left(19^{\circ}-20^{\circ} \mathrm{S}, 43^{\circ}-44^{\circ} \mathrm{W}\right. \\
\text { and } 20^{\circ} 00^{\prime}-20^{\circ} 30^{\prime} \mathrm{S}, 46^{\circ} 15^{\prime}- \\
\left.47^{\circ} 00^{\prime} \mathrm{W}\right)\end{array}$ & (Callisto et al., in press) \\
\hline Corynoneura & $\begin{array}{l}\text { Corydalus nubilus } \\
\text { Erichson, } 1848 \\
\text { (Megaloptera) }\end{array}$ & $\begin{array}{l}\text { Stream (Igarapé), Presidente } \\
\text { Figueiredo, Amazonas } \\
\left(02^{\circ} 01^{\prime} 07^{\prime \prime} \mathrm{S}, 59^{\circ} 49^{\prime} 28^{\prime \prime} \mathrm{W}\right)\end{array}$ & $\begin{array}{c}\text { C. A. S. de Azevedo and S. } \\
\text { R. M.Couceiro (data } \\
\text { unpublished) }\end{array}$ \\
\hline Corynoneura group & $\begin{array}{c}\text { Kempnyia colossica } \\
\text { Navás, } 1934 \text { (Plecoptera) }\end{array}$ & $\begin{array}{c}\text { Stream, P.E.Intervales, São } \\
\text { Paulo }\left(24^{\circ} 18^{\prime} \mathrm{S}, 48^{\circ} 25^{\prime} \mathrm{W}\right)\end{array}$ & Present study \\
\hline Corynoneura group & Farrodes (Ephemeroptera) & $\begin{array}{l}\text { Stream, Estação Biológica de } \\
\text { Boracéia, São Paulo (233'ㅇ, }\end{array}$ & Present study \\
\hline Corynoneura group & Corydalus (Megaloptera) & $\begin{array}{l}\text { Stream, Ipeúna, São Paulo } \\
\left(22^{\circ} 22^{\prime} 42^{\prime \prime} \mathrm{S}, 47^{\circ} 46^{\prime} 40^{\prime \prime} \mathrm{W}\right)\end{array}$ & Present study \\
\hline Corynoneura group & Argia (Odonata) & $\begin{array}{l}\text { Stream, Estação Biológica de } \\
\text { Boracéia, São Paulo ( } 23^{\circ} 32^{\prime} \mathrm{S}, \\
\left.45^{\circ} 51^{\prime} \mathrm{W}\right)\end{array}$ & Present study \\
\hline Corynoneura group & Corydalus (Megaloptera) & $\begin{array}{c}\text { Stream, Estação Biológica de } \\
\text { Boracéia, São Paulo }\left(23^{\circ} 32^{\prime} \mathrm{S},\right. \\
\left.45^{\circ} 51^{\prime} \mathrm{W}\right)\end{array}$ & Present study \\
\hline Corynoneura group & Belastomatidae (Hemiptera) & $\begin{array}{l}\text { Stream, Ipeúna, São Paulo } \\
\left(22^{\circ} 22^{\prime} 42^{\prime} \mathrm{S}, 47^{\circ} 46^{\prime} 40^{\prime} \mathrm{W}\right)\end{array}$ & Present study \\
\hline Cricotopus & $\begin{array}{l}\text { Corydalus nubilus } \\
\text { Erichson, } 1848 \\
\text { (Megaloptera) }\end{array}$ & $\begin{array}{l}\text { Stream (Igarapé), Presidente } \\
\text { Figueiredo, Amazonas } \\
\left(02^{\circ} 01^{\prime} 07^{\prime} \text { S, 5949'28” W) }\right.\end{array}$ & $\begin{array}{c}\text { C. A. S. de Azevedo and S. } \\
\text { R. M.Couceiro (data } \\
\text { unpublished) }\end{array}$ \\
\hline Endotribelos & Leptoceridae (Trichoptera) & $\begin{array}{c}\text { Stream,Cananéia, São Paulo } \\
\left(24^{\circ} 54^{\prime} 12.6^{\prime} \text { S }, 47^{\circ} 58^{\prime} 36.9^{\prime \prime}\right. \\
\text { W) }\end{array}$ & Present study \\
\hline $\begin{array}{l}\text { Goeldichironomus } \\
\text { neopictus Trivinho- } \\
\text { Strixino \& Strixino, }\end{array}$ & Pomacea (Mollusca) & $\begin{array}{l}\text { Stream, São Carlos, SP } \\
\left(22^{\circ} 00^{\prime} \mathrm{S}, 47^{\circ} 54^{\prime} \mathrm{W}\right)\end{array}$ & Present study \\
\hline Ichthyocladius & Kronichtys (Pisces) & $\begin{array}{c}\text { Stream, P.E. Intervales, São } \\
\text { Paulo }\left(24^{\circ} 18^{\prime} \mathrm{S}, 48^{\circ} 25^{\prime} \mathrm{W}\right)\end{array}$ & (Mendes et al., in press) \\
\hline Ichthyocladius & Harttia spp (Pisces) & $\begin{array}{c}\text { São Francisco River } \\
\left(20^{\circ} 30^{\prime} 0^{\prime} \mathrm{S}, 46^{\circ} 50^{\prime} 0^{\prime} \mathrm{W}\right)\end{array}$ & (Mendes et al., in press) \\
\hline Ichthyocladius & $\begin{array}{c}\text { Hypostomus cf. garmani } \\
\text { (Pisces) }\end{array}$ & $\begin{array}{c}\text { São Francisco River } \\
\left(20^{\circ} 30^{\prime} 0^{\prime} \mathrm{S}, 46^{\circ} 50^{\prime} 0^{\prime \prime} \mathrm{W}\right) \\
\end{array}$ & (Mendes et al., in press) \\
\hline Ichthyocladius & $\begin{array}{l}\text { Ancistrus brevipinnis } \\
\text { (Regan, 1904) (Pisces) }\end{array}$ & Brazil & $\begin{array}{c}\text { Fittkau (1974) and } \\
\text { Freihofer \& Neil (1967) }\end{array}$ \\
\hline Ichthyocladius & $\begin{array}{l}\text { Ancistrus bufonius } \\
\text { (Valenciennes, 1840) } \\
\text { (Pisces) } \\
\end{array}$ & Brazil & $\begin{array}{c}\text { Fittkau (1974) and } \\
\text { Freihofer \& Neil (1967) }\end{array}$ \\
\hline Ichthyocladius & $\begin{array}{c}\text { Ancistrus triradiatus } \\
\text { (Pisces) }\end{array}$ & Brazil & $\begin{array}{c}\text { Fittkau (1974) and } \\
\text { Freihofer \& Neil (1967) }\end{array}$ \\
\hline
\end{tabular}




\begin{tabular}{|c|c|c|c|}
\hline Ichthyocladius & $\begin{array}{l}\text { Ancistrus cirrhosus? } \\
\text { (Valenciennes, 1836) } \\
\text { (Pisces) }\end{array}$ & Iguassu River, Brazil & $\begin{array}{c}\text { Fittkau (1974) and } \\
\text { Freihofer \& Neil (1967) }\end{array}$ \\
\hline Ichthyocladius & $\begin{array}{l}\text { Plecostomus strigatceps } \\
\text { (Regan, 1908) (Pisces) }\end{array}$ & Mogi-Guassu River, São Paulo & $\begin{array}{c}\text { Fittkau (1974) and } \\
\text { Freihofer \& Neil (1967) }\end{array}$ \\
\hline Ichthyocladius & $\begin{array}{c}\text { Xenocara gymnorhynchus } \\
\text { (Pisces) }\end{array}$ & Brazil & $\begin{array}{c}\text { Fittkau (1974) and } \\
\text { Freihofer \& Neil (1967) }\end{array}$ \\
\hline Ichthyocladius & $\begin{array}{c}\text { Trichomycterus } \\
\text { mirissumba (Costa, 1992) } \\
\text { (Pisces) }\end{array}$ & Preto River, Rio de Janeiro & Nessimian et al. (2003) \\
\hline Ichthyocladius & $\begin{array}{l}\text { Pareiorhina rudolphi } \\
\text { (Gosline, 1947) (Pisces) }\end{array}$ & Preto River, Rio de Janeiro & Nessimian et al. (2003) \\
\hline Ichthyocladius & $\begin{array}{l}\text { Hisonotus depressicalda } \\
\text { (Miranda-Ribeiro, 1918) }\end{array}$ & $\begin{array}{l}\text { Stream, Ipeúna, São Paulo } \\
\left(22^{\circ} 22^{\prime} 42^{\prime} \text { 'S } 47^{\circ} 46^{\prime} 40^{\prime} \mathrm{W}\right)\end{array}$ & Present study \\
\hline Ichthyocladius & Hypostomus (Pisces) & $\begin{array}{l}\text { Stream, Ipeúna, São Paulo } \\
\left(22^{\circ} 22^{\prime} 42^{\prime \prime S}, 47^{\circ} 46^{\prime} 40^{\prime \prime} \mathrm{W}\right)\end{array}$ & Present study \\
\hline Ichthyocladius & $\begin{array}{l}\text { Corumbataia cuestae } \\
\text { Britski, } 1997 \text { (Pisces) }\end{array}$ & $\begin{array}{l}\text { Stream, Ipeúna, São Paulo } \\
\left(22^{\circ} 22^{\prime} 42^{\prime \prime S}, 47^{\circ} 46^{\prime} 40^{\prime \prime}\right)\end{array}$ & Present study \\
\hline Ichthyocladius & Hypostomus (Pisces) & $\begin{array}{c}\text { Stream, Araraquara, São Paulo } \\
\left(21^{\circ} 49^{\prime} \mathrm{S}, 47^{\circ} 57^{\prime} \mathrm{W}\right) \\
\end{array}$ & Present study \\
\hline Ichthyocladius & $\begin{array}{c}\text { Kronichthys heylandis } \\
\text { (Boulenger, 1900) (Pisces) }\end{array}$ & $\begin{array}{l}\text { Stream, P.E. Intervales, São } \\
\left.\text { Paulo (24 } 24^{\circ} 18^{\prime} S, 48^{\circ} 25^{\prime} \mathrm{W}\right)\end{array}$ & Sazima et al. (2001) \\
\hline Ichthyocladius & Ancistrus sp (Pisces) & $\begin{array}{l}\text { Stream, P.E. Intervales, São } \\
\left.\text { Paulo (24'18'S, } 48^{\circ} 25^{\prime} \mathrm{W}\right)\end{array}$ & Sazima et al. (2001) \\
\hline Ichthyocladius & Ancistrus sp. (Pisces) & $\begin{array}{c}\text { Stream Reserva Biológica da } \\
\text { Serra Geral, Rio Grande do Sul } \\
\left(29^{\circ} 32^{\prime}-29^{\circ} 38^{\prime} \mathrm{S} ; 50^{\circ} 08^{\prime}-\right. \\
\left.50^{\circ} 13^{\prime} \mathrm{W}\right)\end{array}$ & Villela et al. (2002) \\
\hline Ichthyocladius & $\begin{array}{l}\text { Hemipsilichthys nudulus } \\
\text { Reis \& Pereira (Pisces) }\end{array}$ & $\begin{array}{c}\text { Stream Reserva Biológica da } \\
\text { Serra Geral, Rio Grande do Sul } \\
\left(29^{\circ} 32^{\prime}-29^{\circ} 38^{\prime} \text { S; } 50^{\circ} 08^{\prime}-\right. \\
\left.50^{\circ} 13^{\prime} \mathrm{W}\right)\end{array}$ & Villela et al. (2002) \\
\hline Ichthyocladius & $\begin{array}{l}\text { Hemipsilichthys } \\
\text { sp.1(Pisces) }\end{array}$ & $\begin{array}{c}\text { Stream Reserva Biológica da } \\
\text { Serra Geral, Rio Grande do Sul } \\
\left(29^{\circ} 32^{\prime}-29^{\circ} 38^{\prime} \mathrm{S} ; 50^{\circ} 08^{\prime}-\right. \\
\left.50^{\circ} 13^{\prime} \mathrm{W}\right) \\
\end{array}$ & Villela et al. (2002) \\
\hline Ichthyocladius & $\begin{array}{l}\text { Hemipsilichthys sp. } 2 \\
\text { (Pisces) }\end{array}$ & $\begin{array}{c}\text { Stream Reserva Biológica da } \\
\text { Serra Geral, Rio Grande do Sul } \\
\left(29^{\circ} 32^{\prime}-29^{\circ} 38^{\prime} \mathrm{S} ; 50^{\circ} 08^{\prime}-\right. \\
\left.50^{\circ} 13^{\prime} \mathrm{W}\right) \\
\end{array}$ & Villela et al. (2002) \\
\hline Nanocladius & Traulodes (Ephemeroptera) & $\begin{array}{l}\text { Stream, Serra do Cipó, Minas } \\
\text { Gerais }\left(19^{\circ}-20^{\circ} \mathrm{S}, 43^{\circ}-44^{\circ} \mathrm{W}\right)\end{array}$ & Callisto \& Goulart (2000) \\
\hline Nanocladius & $\begin{array}{c}\text { Kempnyia tijucana } \\
\text { Dorvillé \& Froehlich } 1997 \\
\text { (Plecoptera) }\end{array}$ & $\begin{array}{c}\text { Stream, P.N. da Tijuca, Rio de } \\
\text { Janeiro }\left(22^{\circ} 55^{\prime} S-23^{\circ} 00^{\prime} \text { S and }\right. \\
\left.43^{\circ} 11^{\prime} \mathrm{W}-43^{\circ} 19^{\prime} \mathrm{W}\right) \\
\end{array}$ & Dorvillé et al. (2000) \\
\hline Nanocladius & Perlidae (Plecoptera) & $\begin{array}{c}\text { Stream Reserva Biológica da } \\
\text { Serra Geral, Rio Grande do Sul }\end{array}$ & Villela et al. (2002) \\
\hline Nanocladius sp.1 & Anacroneura (Plecoptera) & 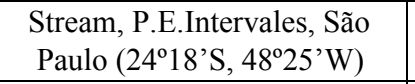 & Present study \\
\hline Nanocladius sp.2 & Anacroneura (Plecoptera) & $\begin{array}{l}\text { Stream, P.E.Intervales, São } \\
\text { Paulo }\left(24^{\circ} 18^{\prime} \mathrm{S}, 48^{\circ} 25^{\prime} \mathrm{W}\right) \\
\end{array}$ & Present study \\
\hline Parachironomus & Pomacea (Mollusca) & $\begin{array}{l}\text { Stream, São Carlos, SP } \\
\left(22^{\circ} 00^{\prime} \mathrm{S}, 47^{\circ} 54^{\prime} \mathrm{W}\right)\end{array}$ & Present study \\
\hline
\end{tabular}




\begin{tabular}{|c|c|c|c|}
\hline Parachironomus & Cordylophora (Hydrozoa) & $\begin{array}{c}\text { Paraná River, Três Lagoas, } \\
\text { São Paulo/Mato Grosso do Sul } \\
\left(20^{\circ} 45^{\prime} \mathrm{S}, 51^{\circ} 40^{\prime} \mathrm{W}\right)\end{array}$ & Present study \\
\hline Rheotanytarsus & Libellulidae (Odonata) & $\begin{array}{l}\text { Stream (Igarapé), Presidente } \\
\text { Figueiredo, } \\
\text { Amazonas }\left(02^{\circ} 01^{\prime} 07^{\prime} \mathrm{S},\right. \\
\left.59^{\circ} 49^{\prime} 28^{\prime} \mathrm{W}\right)\end{array}$ & $\begin{array}{c}\text { C. A. S. de Azevedo and S. } \\
\text { R. M.Couceiro (data } \\
\text { unpublished) }\end{array}$ \\
\hline Rheotanytarsus & $\begin{array}{c}\text { Elasmothemis } \\
\text { cannacrioides (Calv., } \\
\text { 1906) (Odonata) }\end{array}$ & 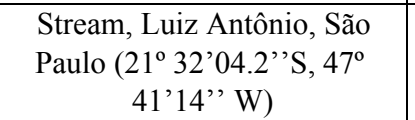 & $\begin{array}{c}\text { Ferreira-Peruquetti \& } \\
\text { Trivinho-Strixino (2003) }\end{array}$ \\
\hline Rheotanytarsus & Heteragrion (Odonata) & $\begin{array}{l}\text { Stream, Campos de Jordão, } \\
\text { São Paulo }\left(22^{\circ} 30^{\prime}-22^{\circ} 41^{\prime} \mathrm{S},\right. \\
\left.45^{\circ} 27^{\prime} \mathrm{S}-45^{\circ} 31^{\prime} \mathrm{W}\right)\end{array}$ & $\begin{array}{l}\text { Ferreira-Peruquetti \& } \\
\text { Trivinho-Strixino }(2003)\end{array}$ \\
\hline Rheotanytarsus & Castoreschna (Odonata) & $\begin{array}{l}\text { Stream, Campos de Jordão, } \\
\text { São Paulo }\left(22^{\circ} 30^{\prime}-22^{\circ} 41^{\prime} S \text {, }\right. \\
\left.45^{\circ} 27^{\prime} S-45^{\circ} 31^{\prime} \mathrm{W}\right)\end{array}$ & $\begin{array}{l}\text { Ferreira-Peruquetti \& } \\
\text { Trivinho-Strixino (2003) }\end{array}$ \\
\hline Rheotanytarsus & $\begin{array}{c}\text { Elasmothemis } \\
\text { cannacrioides (Calv., } \\
\text { 1906) (Odonata) }\end{array}$ & $\begin{array}{l}\text { Stream, Ipeúna, São Paulo } \\
\left(22^{\circ} 22^{\prime} 42^{\prime \prime} \text { S, 4746'40”W) }\right.\end{array}$ & Present study \\
\hline Rheotanytarsus & $\begin{array}{l}\text { Elasmothemis constricta } \\
\text { (Calv., 1898) (Odonata) }\end{array}$ & Stream, Corumbataí, São Paulo & Present study \\
\hline Rheotanytarsus & Argia (Odonata) & $\begin{array}{l}\text { Stream, Estação Biológica de } \\
\text { Boracéia, São Paulo }\left(23^{\circ} 32^{\prime} \mathrm{S},\right. \\
\left.45^{\circ} 51^{\prime} \mathrm{W}\right)\end{array}$ & Present study \\
\hline Thienemaniella & $\begin{array}{l}\text { Corydalus nubilus } \\
\text { Erichson, } 1848 \\
\text { (Megaloptera) }\end{array}$ & $\begin{array}{l}\text { Stream (Igarapé), Presidente } \\
\text { Figueiredo, Amazonas } \\
\left(02^{\circ} 01^{\prime} 07^{\prime \prime} \mathrm{S}, 59^{\circ} 49^{\prime} 28^{\prime \prime} \mathrm{W}\right)\end{array}$ & $\begin{array}{c}\text { C. A. S. de Azevedo and S. } \\
\text { R. M.Couceiro (data } \\
\text { unpublished) }\end{array}$ \\
\hline Thienemanniella & $\begin{array}{c}\text { Argia modesta Selys } \\
\text { (Odonata) }\end{array}$ & $\begin{array}{c}\text { Stream, Campos de Jordão, } \\
\text { São Paulo }\left(22^{\circ} 30^{\prime}-22^{\circ} 41^{\prime} \text { S, }\right. \\
\left.45^{\circ} 27^{\prime} \mathrm{S}-45^{\circ} 31^{\prime} \mathrm{W}\right)\end{array}$ & $\begin{array}{c}\text { Ferreira-Peruquetti \& } \\
\text { Trivinho-Strixino (2003) }\end{array}$ \\
\hline
\end{tabular}


with a commensal ancestor deserves more attention.

\subsection{Distribution of the ICH cases in Brazil}

The ICH occurrences reported here, including in Amazonas, São Paulo, Goiás, Minas Gerais, Rio Grande do Sul and Rio de Janeiro states, seem to indicate that $\mathrm{ICH}$ occurs in a wide area in Brazil. The number of cases per region may simply reflect the sampling effort and number of research in the Southern region. The majority of the Brazilian occurrences came from studies that were not specifically designed to answer quantitative questions on ICH, so that it is difficult to portray how common or rare the $\mathrm{ICH}$ are in frequency, abundance, and distribution.

Most occurrences have come from lotic aquatic systems. Unfortunately, data on Chironomidae and their hosts is scarce in lentic systems. Therefore, although it may be premature to seek broad answers to questions like whether or not Chironomidae living on other animals are more common in certain habitats, some reasonable predictions that merit further investigation can be offered. First, considering the possible benefits of commensalism in the chironomid discussed by Tokeshi (1995), ICH should be more common in lotic system. Second, considering that many chironomids and their potential hosts may have low tolerance to some kinds of antropic impacts, the richness of ICH must be lower in impacted areas.

\subsection{Methodological constraints}

Tokeshi (1995) points out that studies of ecological relationships often lack sufficient analytical rigor. Several aspects contribute to this situation: most of the relationships are established by observing dead organisms or live organisms under artificial conditions, little information about population dynamics of the species involved are available, and the behavior of the majority of the larvae is unknown. Moreover, basic questions such as whether the larvae benefit the host organism in any way (for example, cleaning some parts of their body) and how the chironomid larvae (e.g. Ichthyocladius) colonize the host organism remain unanswered. In the majority of the cases, we assume that the interaction between a chironomid larvae and larger animals may benefit the larvae by decreasing predation risks, increasing mobility, improving protection from disturbances, improving opportunity to feed, and also eliminating metabolic waste (Saffo 1992, Tokeshi 1993). However, there is not much information about it in natural environments.

Food relationships are extremely difficult to define for a group of insects like the chironomids, which have a varied natural diet (Pinder 1986). The association between Nanocladius and mayfly nymphs (Jacobsen 1995 for review) represents a good example of the challenge to establish the ecological category that depends on information about food relations. In the literature, we find different levels of interactions and/or different interpretations, such as phoresy (Callisto \& Goulart 2000; Vilella et al. 2002), symphoresy (Epler 1986), symbiosis (Jacobsen 1995) and parasitism (Doucett et al. 1999; Caldwell \& Wiersema 2002). This diversity of categories may originate from different aspects: (1) conceptual confusion, (2) behavior flexibility or different feeding strategies of the Nanocladius larvae (Vilella et al. 2002), (3) different levels of association between Nanocladius species and their hosts, and (4) use of different criteria and analytical tools to establish the relationship.

Because of the breadth and complexity of potential factors involved in relationships in natural systems, some degree of flexibility in applying criteria to establish the ecological relationship is necessary. However, for the sake of comparison and communication, some standardization is also needed. Some comments that may be useful for future research are included below.

Evaluation of possible injuries caused by the larvae to host organisms (e.g. gill deformation) and the position and location of the larvae may indicate indirectly some interactions, but it is important to note that the position of the larvae may result from environmental stimuli, life stage, feeding behavior and others.

The larvae oriented with their heads facing the body of the host may be interpreted as a sign of feeding behavior and, consequently, of parasitism, but this position may also represent that the larvae ceased feeding and started the pupation process or yet this position may be related to negative phototaxis when observed in stereomicroscope with high light.

Direct behavior observation of larvae and their hosts, considering ethological approaches and including behavior quantitative analysis, are strongly recommended to elucidate possible interactions (for example, whether the larvae clean the body of their hosts).

Indirect observation of possible activity or their effects may also contribute to establish the relationship. For example, Svensson (1980) noted lower densities of ciliates on the bodies of a mayfly when the Epoicocladius flavens (Mallock) larvae were present, indicating that the larvae probably clean the host body. Another example is provided by Condreanu (1939). His study of the relationship between Symbiocladius rhithrogenae (Zavr.) and nymphs of Ephemeroptera demonstrated that the larvae feed on the host's hemolymph and induce a cancer-like proliferation of blood cells within the host that may be beneficial to the larvae.

Analysis of larval gut contents by direct observation through a microscope can help the interpretation of the relationship, but it is not sufficient to know whether the larvae feed or not from parts of their hosts, because is practically impossible to observe haemolymph in gut contents. 
Thus, the use of other methodologies, such as stable isotope analysis as reported by Doucett et al. (1999), is advisable.

Studies focusing in population dynamics of chironomid and their hosts (e.g. Svensson 1980; Peckarsky \& Cowan 1991; Pennuto 1998; Pennuto 2000) are fundamental to understand the ecological aspects of inter and intraspecific interactions of larvae on hosts and set up the mechanisms and effects of interaction between them. Furthermore, symbiotic interaction categories and a cost-benefit model for the evolution of symbiosis (Matsuda \& Shimada 1993) should be established considering the fitness involved in the relationships. Hence, information about a possible increase of fit or not of both participants associated is necessary.

Another aspect to be considered is the interspecific relationship within community and ecosystem context, regarding ecological and evolutionary perspectives, as pointed out by Abrams (1987), Kawanabe \& Iwasaki (1993), Tokeshi (1999) and Vilella et al. (2002). According to Abrams (1987), ecologists should realize that the interaction between two populations may change when the size of the populations changes or when other populations with which they interact change, and it depends on many other biotic and abiotic factors working in multiple spatial and temporal scales. Ecological interactions are not fixed entities that can be easily classified.

\section{Acknowledgements}

We thank Dr. Mathias Wantzen, Dr. Jan Frouz, Marcos Yukio Yoshinaga, Humberto Mendes and Tadeu Siqueira Barros for suggestions in this manuscript, Mateus Pepineli, Humberto Mendes, and Alexandre Kannebley for material from Goiás, Intervales and Araraquara respectively, and all the researchers cited in Table 1 for personal communications and confidence in our work. We also thank Patricia Ferreira-Peruquetti and Valdelânia Ribeiro for Odonata and Plecoptera identifications, respectively. We thank Peter J. de Jancso for helping with English grammar and vocabulary. The State of São Paulo Research Foundation (FAPESP) within the BIOTA/FAPESP - The Biodiversity Virtual Institute Program (www.biotasp.org.br) and Coordenação de Aperfeiçoamento de Pessoal de Nível Superior (CAPES) sponsored this work.

\section{References}

1.ABRAMS, P.A. 1987. On classifying interactions between populations. Oecologia (Berlin) 73:272-281.

2.ASHE, P. \& O'CONNOR, J.P. 2002. A review of the known associations, commensal, phoretic and ectoparasitic, involving the aquatic stages of Chironomidae with Trichoptera. Nova Supp. Ent. 15:467-480.
3.BRONSTEIN, J.L. 2001. The exploitation of mutualisms. Ecology Letters 4:277-287.

4.CALDWELL, B.A. \& WIERSEMA, N.A. 2002. New record and observation for parasitic chironomid midges (Diptera: Chironomidae) and their mayflies (Ephemeroptera) hosts. Entomol. News 113:11-14.

5.CALLISTO, M. \& GOULART, M.D.C. 2000. Phoretic association between Nanocladius (Plecopteracoluthus) sp. (Chironomidae: Diptera) and Thraulodes sp. (Lepptophlebiidae: Ephemeptera). An. Soc. Entomol. Brasil. 29:605-608.

6.CALLISTO, M., GOULART, M., MORENO, P. \& MARTINS, R.P. (in press). Predator benefits prey: phoresy between cf Corynoneura (Diptera: Chironomidae) and Corydalus (Megaloptera: Corydalidae). J. Insect Behav. 45.

7.CONDREANU, R. 1939. Recherches biologiques sur um Chironomidae, Symbiocladius rhithrogenae (Zavr.), ectoparasite "cancérigéne" des Éphéméres torrenticoles. Arch. Zool. Exp. Gen. 81:1-283.

8.DE LA ROSA, C.L. 1992. Phoretic associations of Chironomidae (Diptera) on Corydalidae (Megaloptera) in northewestern Costa Rican streams. J. North. Am. Benthol. Soc. 11:316-323.

9.DORVILLÉ, L.F.M., NESSIMIAN, J.L. \& SANSEVERINO, A.M. 2000. First record of S symphoresy between nymphs of stonefly Kempya tijucana (Plecoptera, Perlidae) and chironomid larvae, Nanocladius (Plecopteracoluthus) sp., in the Neotropics. Stud. Neotrop. Fauna Environ. 35:109-114.

10.DOUCETT, R.R., GIBERSON, D.J. \& POWER, G. 1999: Parasitic association of Nanocladius (Diptera: Chironomidae) and Pteronarcys biloba (Plecoptera: Pteronarcyidae): insights from stable-isotope analysis. J. North. Am. Benthol. Soc. 18:514-523.

11.EPLER, J.H. 1986. A novel new Neotropical Nanocladius (Diptera: Chironomidae), symphoretic on Traverella (Ephemeroptera: Leptophlebiidae). Fla. Entomol. 69:319327.

12.EPLER, J.H. \& DE LA ROSA, C.L. 1995: Tempisquitoneura, a new genus of Neotropical Orthocladiinae (Diptera: Chironomidae) symphoretic on Corydalus (Megaloptera: Corydalidae). J. North. Am. Benthol. Soc. 14:50-60.

13.FERREIRA-PERUQUETTI, P. \& TRIVINHO-STRIXINO, S. 2003. Relação forética entre espécies de Chironomidae e Odonata do Estado de São Paulo. Entomotropica 18:149-151. 
14.FITTKAU, E.J. 1974. Ichtiocladius n. gen., eine neotropische Gattung der Orthocladiinae (Chironomidae, Diptera) deren Larven epizoisch auf Welsen (astroblepidae und Loricariidae) Leben. Ent. Tidskr. Suppl. 95:91-106.

15.FRAGOSO, E.N., ROQUE, F.O., SOUZA, J.E., JANCSO, M.A., FENERICH-VERANI, N. \& TRIVINHO-STRIXINO, S. 2003. Relação de forese entre Icthyocladius (Diptera, Chironomidae) e cascudos (Pisces, Siluriformes) na microbacia do córrego da Lapa, Ipeúna/Itirapina, Estado de São Paulo. XV Encontro Brasileiro de Ictiologia (EBI), São Paulo. Resumos em CD-ROM. p.108.

16.FREIHOFER, W. \& NEIL, E.H. 1967. Commensalism between midge larvae (Diptera: Chironomidae) and catfishes of the families Astoblepidae and Loricariidae. Copeia 1:39-45.

17.GONSER, T. \& SPIES, M. 1997. Southern hemisphere Symbiocladius (Diptera: Chironomidae) and their mayfly hosts (Ephemeroptera, Leptophlebiidae). In: Landolt P P, Sartoni M. (eds). Ephemeroptera \& Plecoptera: biology-ecology-systematics. MTL, Fribourg. p.455-466.

18.JACOBSEN, R.E. 1995: Symbiotic associations between Chironomidae (Diptera) and Ephemeroptera. In: Corkum LD, Ciborowski JJH (eds.). Current directions in research on Ephemeroptera.. Canadian Scholars' Press, Toronto, p.317-332.

19.KAWANABE, H. \& IWASAKI, K. 1993. Introduction: flexibility and synergism of biological relationships in natural communities. In: Kawanabe H, Cohen JE (eds). Mutualism and community organization: behavioral, theoretical and food-web approaches. Oxford Science Publications, p.1-10.

20.MATSUDA, H. \& SHIMADA, M. 1993. Cost-benefit model for the evolution of symbiosis. In: Kawanabe H, Cohen JE (eds). Mutualism and community organization: behavioral, theoretical and food-web approaches. Oxford Science Publications, p. 228-237.

21.MENDES, H.,ANDERSEN, T. \& SÆTHER, O. (2004): New species of Ichthyocladius Fittkau, a member of the Corynoneura-group (Diptera: Chironomidae: Orthocladiinae), with a review of the genus. Stud. Neotrop. Fauna Environ. 39:15-35.

22.NESSIMIAN, J. L., AMORIM, R. M., HENRIQUESOLIVEIRA, A. L. \& SANSEVERINO, A. M. 2003. Chironomidae (Diptera) do Estado do Rio de Janeiro: levantamento dos gêneros e hábitats de ocorrência. Publ. Avul. Mus. Nac. 98:3-16.

23.PECKARSKY, B.L. \& COWAN, C.A. 1991. Consequences of larval intraspecific competition to stonefly growth and fecundity. Oecologia 88:277-288.
24.PENNUTO, C.M. 1998. Seasonal position patterns and fate of a commensal chironomid on its fishfly host. J. Freshwater Ecol. 13:323-332.

25.PENNUTO, C.M. 2000. Effects of larval movement behavior and density on emergence success and adult body size in a commensal midge. Aquatic Ecology 34:177184.

26.PINDER, L.C.V. 1986. Biology of freshwater Chironomidae. Annu. Rev. Entomol. 31:1-23.

27.ROBACK, S.S. 1977. First record of a chironomid larva living phoretically on an aquatic hemipteran (Naucoridae). Entomol. News 88:192.

28.SAFFO, M.B. 1992. Invertebrates in endosymbiotic associations. Am. Zool. 32:557-565.

29.SAZIMA, I., BUCK, S. \& SABINO, J. 2001. Peixes de riachos. In: Fundação Florestal, Secretaria do Meio Ambiente do Estado de São Paulo, Governo do Estado de São Paulo (eds). Intervales. São Paulo. p.169-179.

30.STEFFAN, A.W. 1967. Ectosysmbiosis in aquatic insects. In: Henry S.M (ed). Symbiosis. Academic Press, New York and London. p.207-289.

31.SVENSSON, B.S. 1980. The effect of host density on the success of commensalistic Epoicocladius flavens (Chironomidae) in utilizing streamliving Ephemera danica (Ephemeroptera). Oikos 34:326-336.

32.TOKESHI, M. 1993. On the evolution of commensalism in the Chironomidae. Freshwater Biol. 29:481-489.

33.TOKESHI, M. 1995. Species interactions and community structure. In: Armitage PD, Cranston PS, Pinder LCV (eds). Biology and ecology of non-biting midges. Chapman \& Hall, London, p.297-335.

34.TOKESHI, M. 1999. Species coexistence: ecological and evolutionary perspectives. Blackwell Science. Oxford.

35.VILELLA, F.S., RODRIGUES, G.G., BARBIERI, G. \& HARTZ, S.M. 2002. Forese como estratégia adaptativa da comunidade bentônica ao longo de um riacho de $1^{\mathrm{a}}$ ordem na Mata Atlântica no sul do Brasil. Dissertação de Mestrado, Universidade Federal de São Carlos, São Carlos.

36.WHITE, T.R., WEAVER, III J.S. \& FOX, R.C. 1980. Phoretic relationships between Chironomidae (Diptera) and benthic macroinvertebrates. Entomol. News 9:69-74.

Title: Records of Chironomidae Larvae Living on Other Aquatic Animals in Brazil

Authors: Fabio de Oliveira Roque, Susana TrivinhoStrixino, Mário Jancso, Evelise N. Fragoso

Biota Neotropica, Vol. 4 ( number 2): 2004

http://www.biotaneotropica.org.br/v4n2/pt/

abstract?short-communication+bn03404022004

Date Received 03/16/2004 -Revised 08/26/2004

Accepted 09/08/2004 - ISSN 1676-0611 